\title{
Intake of cattle offered normal and lodged tall fescue swards
}

\author{
CHARLES T. DOUGHERTY AND PAUL L. CORNELIUS
}

Authors are professor, Department of Agronomy, University of Kentucky, Lexington Kentucky, 40546-0091 and professor, Departments of Agronomy and Statistics, University of Kentucky, Lexington, Kentucky, 40546-0091.

Abstract

Grazing behavior of livestock may be altered when grass swards are lodged by trampling or wind and rain. We used a balanced change-over design to investigate the effects of lodging on the ingestive behavior of Angus cows (Bos taurus L.)(mass (M): $344 \mathrm{~kg}$ ) grazing swards of vegetative endophytefree 'Kenhy' tall fescue (Festuca arundinacea Schreb.). Animals were offered normal swards $\left(T_{1}\right)$, lodged swards $\left(T_{2}\right)$, or swards with one half of their area lodged $\left(\mathbf{T}_{3}\right)$. To simulate lodging, swards were covered overnight with weighted plywood sheets that compressed sward surface height (SSH) from 34 to $14 \mathrm{~cm}$ and elevated sward dry matter (DM) density from 151 to $499 \mathrm{~kg} \mathrm{ha}^{-1} \mathrm{~cm}^{-1}$ for herbage $>5 \mathrm{~cm}$. Mean herbage DM intake per bite was $561 \mathrm{mg}$ for $T_{1}, 713 \mathrm{mg}$ for $T_{2}$ and $792 \mathrm{mg}$ for $T_{3}$. Cattle grazed at 28 bites min $^{-1}$ for $T_{1}$, and 25 bites min${ }^{1}$ for both $T_{2}$ and $T_{3}$. Herbage $D M$ intake rates were $0.27,0.31$,

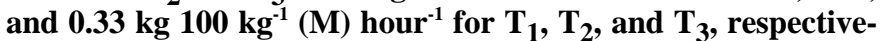
ly. In another experiment, cattle were offered equal areas of normal swards (SSH: $27 \mathrm{~cm}$ ) and lodged swards (SSH: $16 \mathrm{~cm}$ ), normal and partially defoliated swards (SSH: $20 \mathrm{~cm})$ swards, or lodged and partially defoliated swards. When offered normal and lodged swards, $64 \%$ of DM intake came from normal swards. When offered normal and partially defoliated swards about $60 \%$ of DM intake came from normal swards. Cattle grazed equally on lodged and partially defoliated sward segments when offered that choice.

Key Words: Grazing behavior, ingestive behavior, diet selection, herbage density, sward surface height.

Surface height and bulk density of pastures are involved in the determination of the amount and rate of intake of grazing animals (Ungar et al. 1991, Hodgson et al. 1994). These sward properties are among several that are altered by activities of grazing livestock, by vehicular and human traffic, and by lodging (Edmonds 1964, Abdel-Magid et al. 1987, Dougherty et al. 1989a, Guthery and Bingham 1996, Sheath and Carlson 1998). Lodging of swards by wind and rain is significant in tall fescue (Festuca arundinacea Schreb.) accumulated for hay or deferred grazing (Taylor and Templeton 1976).

This research was supported by Project KY99002 of the Kentucky Agricultural Experiment Station. This paper is published with the approval of the Director, Kentucky Agricultural Experiment Station as Journal Paper 98-06-135.

Manuscript accepted 14 Dec. 1998.

\section{Resumen}

El comportamiento del ganado en apacentamiento puede ser alterado cuando las praderas están acamadas por pisoteo, viento o lluvia. Utilizamos un diseño balanceado "changeover" para investigar los efectos del acame en el comportamiento ingestivo de vacas Angus (Bos taurus L.)(masa (M): $344 \mathrm{~kg}$ ) apacentando praderas alta fescue (Festuca arundinacea Schreb.) var 'Kenhy' en estado vegetativo libres de endofito. A los animales se les ofreció pradera normal (T1), praderas acamadas $\left(T_{2}\right)$ o praderas con la mitad de su área acamada $\left(T_{3}\right)$. Para simular el acame, las praderas se cubrieron durante toda la noche con hojas de madera que comprimieron la altura de la superficie de la pradera (ASP) de 34 a $14 \mathrm{~cm}$ y elevaron la densidad de la materia seca de la pradera de 151 a $499 \mathrm{~kg} \mathrm{ha}^{-1} \mathrm{~cm}^{-1}$ para el forraje > a $5 \mathrm{~cm}$. La media de consumo de materia seca de forraje por bocado fue de $561 \mathrm{mg}$ para el $T_{1}, 713 \mathrm{mg}$ para el $T_{2}$ y $792 \mathrm{mg}$ para $T_{3}$. El ganado apacentó a un ritmo de 28 mordidas min-1 en el $\mathbf{T}_{1}, y$ 25 mordidas min-1 en el $T_{2}$ y $T 3$. Las tasas de consumo de materia seca de forraje fueron $0.27,0.31$ y $0.33 \mathrm{~kg} 100 \mathrm{~kg}^{-1}$ (M) $\mathrm{hr}^{-1}$ para los tratamientos $\mathrm{T}_{1}, \mathrm{~T}_{2}, \mathbf{y} \mathrm{T}_{3}$ respectivamente. En otro experimento, se le ofreció al ganado áreas iguales de pradera normal (ASP: $27 \mathrm{~cm}$ ), pradera acamada (ASP: 16 cm) y pradera normal y parcialmente defoliada (ASP: $20 \mathrm{~cm}$ ) o praderas acamadas y parcialmente defoliadas. Cuando se ofreció praderas normales y acamadas $64 \%$ del consumo de materia seca provino de la pradera normal. Cuando se ofrecio al ganado pradera normal y parcialmente defoliada aproximadamente $60 \%$ del consumode materia seca provino de la pradera normal. El ganado apacentó en forma similar cuando se le ofrecieron a elección propia segmentos de praderas acamadas y parcialmente defoliadas.

Information about lodging effects on processes of ingestion and on diet selection is needed for research in grazing management and the development of simulation models of grazing systems (Bailey et al. 1996, Herrero et al. 1998, Loewer 1998).

To establish the effects of lodging on herbage intake of cattle, we compared grazing of normal swards with grazing of swards that had been compressed to simulate lodging. We also compared herbage intake of cattle offered a choice of normal or compressed swards, normal or partially defoliated swards, and compressed or partially defoliated swards. 


\section{Materials and Methods}

\section{Experiment Design and Statistical Analysis}

We used a 4-period change-over design for 3 treatments and 12 animals previously described (Dougherty et al. 1987, 1989b). This design was constructed by concatenating 3 QuenouilleBerenblut 4 x 4 change-over designs (Quenouille 1953, Berenblut 1964, 1967). The 2 treatments assigned to each $4 \times 4$ square being 1 of 3 possible pairs of 3 treatments. Columns (i.e. animals) in the resulting $4 \times 12$ design constitute a balanced incomplete block design. Rows (i.e. days) of the design are complete blocks containing each of the 3 treatments 4 times. The sequencing of treatments within each column (i.e. animals) is such that the design is balanced for first residual effects.

In Experiment I (Exp. I), the 3 treatments were normal swards $\left(\mathrm{T}_{1}\right)$, compressed swards $\left(\mathrm{T}_{2}\right)$, and swards in which half was normal and the other half compressed $\left(T_{3}\right)$ (Table 1). In one treatment $\left(\mathrm{T}_{1}\right)$ of Experiment II (Exp. II), cattle were offered plots with one half of the sward compressed (Table 1). In the second treatment $\left(\mathrm{T}_{2}\right)$, cattle were offered plots with one half cut to $20 \mathrm{~cm}$ above the soil surface and the herbage removed. In the third treatment $\left(\mathrm{T}_{3}\right)$, cattle were offered plots with one half of the sward surface area compressed and one-half cut to $20 \mathrm{~cm}$, as in $\mathrm{T}_{1}$ and $\mathrm{T}_{2}$, respectively.

The statistical model was:

$\mathrm{Y}_{\mathrm{ijkm}}=\mu+\mathrm{A}_{\mathrm{k}}+\mathrm{D}_{\mathrm{m}}+\mathrm{T}_{\mathrm{i}}+\delta \mathrm{R}_{\mathrm{j}}+\varepsilon_{\mathrm{ijkm}}$ where $Y_{\mathrm{ijkm}}$ is the $\mathrm{m}^{\text {th }}$ day measurement taken on the $\mathrm{k}^{\text {th }}$ animal that received the $\mathrm{i}^{\text {th }}$ treatment on the $\mathrm{m}^{\text {th }}$ day and the $\mathrm{j}^{\text {th }}$ treatment on the $(m-1)^{\text {th }}$ day; $\mu$ is the overall mean, $A_{k}$ is the effect of the $\mathrm{k}^{\text {th }}$ animal, $\mathrm{D}_{\mathrm{m}}$ is the effect of the $\mathrm{m}^{\text {th }}$ day, $\mathrm{T}_{\mathrm{i}}$ is the direct effect of the $\mathrm{i}^{\text {th }}$ treatment, $\delta=1$ if $\mathrm{m}>1$, zero otherwise, and $\mathrm{R}_{\mathrm{j}}$ is the residual (carryover) effect of the $\mathrm{j}^{\text {th }}$ treatment. The random errors, $\varepsilon_{\mathrm{ijkm}}$, are assumed NID $\left(0, \delta^{2}\right)$. Data were analyzed with the General Linear Models procedure of SAS Institute Inc. (1997).

\section{Pasture Management}

We used a monoculture of 'Kenhy' tall fescue that had been established in spring 1988 on Maury silt loam (fine, mixed, mesic Typic Paleudalf) on the
Spindletop research farm of the Kentucky Agricultural Experiment

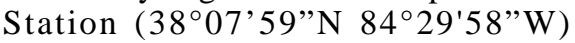
(Table 2). The field was managed in accordance with current Kentucky recommendations for soil fertility and weed and pest control for beef cattle production (Henning and Lacefield 1991). First growth herbage was cut at $5 \mathrm{~cm}$ and harvested as hay on 11 May. Urea-N was applied at $50 \mathrm{~kg} \mathrm{ha}^{-1}$ on 21 May.

Sward compression treatments were applied during the afternoons on the day before plots were scheduled for grazing. In Exp. I, circumferences of $4 \mathrm{~m}^{2}$ plots were delineated by cutting $55-\mathrm{cm}$ wide rings to a height of $5 \mathrm{~cm}$ with a mower tethered to pivots located at plot centers. Two sheets of plywood (1.27 x 122 × 244 $\mathrm{cm})$ were laid on sward surfaces of each plot assigned to the compressed sward treatment $\left(\mathrm{T}_{2}\right)$. One plywood sheet was laid on one half of each plot assigned to the half normal-half compressed treatment $\left(\mathrm{T}_{3}\right)$. Each plywood sheet was weighted with 2 steel rods, each weighing about $5 \mathrm{~kg}$. Plywood was removed each morning just before cattle were introduced to the experimental swards.

Grazing area of plots were $15 \mathrm{~m}^{2}$ in Exp. II. Each plot was dissected by mowing a $50 \mathrm{~cm}$ wide diameter strip. One half of each normal $\left(\mathrm{T}_{1}\right)$ and $\mathrm{T}_{3}$ plot was compressed overnights with weighted plywood sheets, as in Exp. I. For cut halves of $\mathrm{T}_{2}$ and $\mathrm{T}_{3}$ plots, herbage was severed and collected with a $50 \mathrm{~cm}$ wide rotary mower mounted on rails $20 \mathrm{~cm}$ from the soil surface, herbage was dried to a constant weight at $75^{\circ} \mathrm{C}$ (DM removed: $1.01 \pm 0.26 \mathrm{~kg}$ per plot; $674 \pm$ $\left.166 \mathrm{~kg} \mathrm{ha}^{-1}\right)$. Cutting treatments were imposed each morning immediately before grazing commenced.

\section{Animal Management}

Twelve adult Angus cows (mean body mass (M): $344 \pm 24 \mathrm{~kg}$ ), which were experienced in tethered grazing and neither pregnant nor lactating, were used in both experiments. When cattle were not grazing, they were kept in a shaded drylot with unlimited access to water. Cattle were placed on experimental grazing plots at 0900 hours EDT and removed at 1000 hours EDT. At 1300 hours EDT, cows were released for freerange grazing on Kenhy tall fescue pastures and at 1500 hours EDT they were returned to their drylot. Overall management of cows was in accordance with current Kentucky recommendations for nutrition and health of non-pregnant, non-lactating adult cows (Burris and Johns 1991). In Exp. I, mean herbage dry matter (DM) allowance $(>5 \mathrm{~cm})$ was 1.74 $\pm 0.14 \mathrm{~kg}$ animal $^{-1}$ hour $^{-1}$. In Exp. II, herbage DM allowances for the 1-hour grazing period were $7.85 \pm 0.77 \mathrm{~kg}\left(\mathrm{~T}_{1}\right)$, $6.95 \pm 0.73 \mathrm{~kg}\left(\mathrm{~T}_{2}\right)$, and $6.51 \pm 0.64 \mathrm{~kg}$

Table 1. Treatments, sward characteristics, herbage allowances and other initial conditions of Exp. I and Exp. II.

\begin{tabular}{|c|c|c|}
\hline Condition & Exp. I & Exp. II \\
\hline Treatment 1 & Normal swards & Normal/compressed swards \\
\hline Treatment 2 & Compressed swards & Normal/cut swards \\
\hline Treatment 3 & Normal/compressed swards & Compressed/cut swards \\
\hline Measurement phase & 0900-1000 EDT 2-6 July 1990 & 0900-1000 EDT $10-13$ July 1990 \\
\hline Plot area & $4 \mathrm{~m}^{2}$ & $15 \mathrm{~m}^{2}$ \\
\hline Herbage DM content & $234 \pm 20 \mathrm{~g} \mathrm{~kg}^{-1}$ & $236 \pm 56 \mathrm{~g} \mathrm{~kg}^{-1}$ \\
\hline Herbage DM mass & $4,247 \pm 357 \mathrm{~kg} \mathrm{ha}^{-1}$ & $5,100 \pm 745 \mathrm{~kg} \mathrm{~h}^{-1}$ \\
\hline \multirow[t]{2}{*}{ Sward surface height } & Normal: $34.2 \pm 3.7 \mathrm{~cm}$ & Normal: $27.0 \pm 3.4 \mathrm{~cm}$ \\
\hline & Compressed: $14.3 \pm 3.4 \mathrm{~cm}$ & $\begin{array}{l}\text { Compressed: } 15.7 \pm 3.7 \mathrm{~cm} \\
\text { Cut: } 20.0 \pm 2.6 \mathrm{~cm}\end{array}$ \\
\hline \multirow[t]{2}{*}{ Herbage DM density } & Normal: $151 \pm 21 \mathrm{~kg} \mathrm{ha}^{-1} \mathrm{~cm}^{-1}$ & Normal: $246 \pm 61 \mathrm{~kg} \mathrm{ha}^{-1} \mathrm{~cm}^{-1}$ \\
\hline & Compressed: $499 \pm 155 \mathrm{~kg} \mathrm{ha}^{-1} \mathrm{~cm}^{-1}$ & $\begin{array}{l}\text { Compressed: } 386 \pm 191 \mathrm{~kg} \mathrm{ha}^{-1} \mathrm{~cm}^{-1} \\
\text { Cut: } 264 \pm 65 \mathrm{~kg} \mathrm{ha}^{-1} \mathrm{~cm}^{-1}\end{array}$ \\
\hline \multirow[t]{2}{*}{ Extended tiller length } & $48 \pm 6 \mathrm{~cm}$ & Normal: $54 \pm 7 \mathrm{~cm}$ \\
\hline & & Cut: $23.3 \pm 2 \mathrm{~cm}$ \\
\hline Tiller DM mass & $436 \pm 80 \mathrm{mg}$ & $434 \pm 113 \mathrm{mg}$ \\
\hline Pseudostem length & $8.9 \pm 1.5 \mathrm{~cm}$ & $0.9 \pm 1.5 \mathrm{~cm}$ \\
\hline \multirow[t]{3}{*}{ DM allowance } & $1.74 \pm 0.14 \mathrm{~kg}$ & $\mathrm{~T}_{1}: 7.85 \pm 0.77 \mathrm{~kg}$ \\
\hline & & $\mathrm{T}_{2}: 6.95 \pm 0.73 \mathrm{~kg}$ \\
\hline & & $\mathrm{T}_{3}: 6.51 \pm 0.64 \mathrm{~kg}$ \\
\hline
\end{tabular}


Table 2. Location, soil type, experiment design, pasture and animal features common to both Exp. I and Exp. II.

\begin{tabular}{ll}
\hline \hline Conditions & Information \\
\hline Location & Spindletop Farm, Fayette County, Kentucky. Ky Agric. Exp. Sta. \\
Coordinates & $38^{\circ} 07^{\prime} 59^{\prime} \mathrm{N} 84^{\circ} 29^{\prime} 58^{\prime \prime} \mathrm{W}$ \\
Soil type & Maury silt loam (fine, mixed, mesic Typic Paleudalf) \\
Plant species & Festuca arundinacea Schreb. cv Kenhy, endophyte-free \\
Design & Three integrated 4 x 4 change-over designs balanced for first residual effects \\
Animals & Bos taurus L. Adult angus females, non-pregnant, non-lactating \\
& Body mass (M): $344 \pm 24 \mathrm{~kg}$ \\
\hline
\end{tabular}

$\left(\mathrm{T}_{3}\right)$; less in $\mathrm{T}_{2}$ and $\mathrm{T}_{3}$ because one half of plots were defoliated to $20 \mathrm{~cm}$.

\section{Measurements}

Trained observers (one observer per 4 animals) used sound and sight to determine and count prehension bites of each animal sequentially for $1 \mathrm{~min}$ each during measured grazing meals (Dougherty et al. 1987). On divided plots, observers recorded the number of bites taken by cattle from each sector of normal, compressed, or cut swards. Sward surface heights were measured with a height stick at 10 sampling sites at $0.5 \mathrm{~m}$ distances about $20 \mathrm{~cm}$ inside circumferences, before swards treatments were applied, after sward treatments were applied, before grazing commenced, and after cattle were removed from swards.

On each of the 4 days of measurement, herbage of 14 ungrazed control plots, 2 tangential to each grazed plot, and the residual herbage of the 12 grazed plots was cut $(>5 \mathrm{~cm})$ and weighed with a $1.5 \mathrm{~m}$ sickle bar harvester. Samples of herbage were dried to a constant weight at $75^{\circ} \mathrm{C}$ to estimate herbage DM content. Lengths of pseudostems and extended lengths of tillers were measured on 10 tillers per plot sampled from plots before and after grazing at fixed intervals $10 \mathrm{~cm}$ in from the circumference.

Herbage dry matter (DM) allowances were estimated from the mean herbage DM mass $(>5 \mathrm{~cm})$ of 2 tangential ungrazed control plots (each 6 x $1.5 \mathrm{~m}$ ). Herbage DM intake per animal was estimated from the difference between the herbage DM offered and the residual herbage mass of each grazed plot. Herbage DM utilization was estimated from herbage DM intake and herbage DM allowance. Herbage DM intake per bite was derived by dividing herbage DM intake by the product of grazing time and mean rate of biting. Dry matter density of swards was estimated from

\section{Results}

the sward surface height $(>5 \mathrm{~cm})$ and herbage DM mass $(>5 \mathrm{~cm})$. Bite volumes were calculated from bite masses and DM densities of herbage in the grazed horizons.

\section{Weather}

Selected weather variables (Table 3) during the measured grazing periods were obtained from the Spindletop weather station, which is within $50 \mathrm{~m}$ of the site of the experiment, and operated by the Agricultural Weather Center of Kentucky Agr. Exp. Sta., according to specifications of the National Weather Service. Sward surface temperatures during grazing sessions were recorded with an infrared thermometer.

\section{Experiment I}

At the start of Exp. I, herbage dry matter $(\mathrm{DM})$ mass $(>5 \mathrm{~cm})$ of normal (unmodified) swards was 4,247 \pm 357 $\mathrm{kg} \mathrm{ha}^{-1}$ (Table 1). Compression of the sward overnight with weighted plywood significantly lowered the sward surface height from $34.2 \pm 3.7$ to $14.3 \pm 3.4 \mathrm{~cm}$ and increased sward DM density from $151 \pm 21$ to $499 \pm 155 \mathrm{~kg} \mathrm{ha}^{-1} \mathrm{~cm}^{-1}$. Weather was normal during measured grazing meals.

Table 3. Canopy surface temperatures and weather data from the Spindletop weather station during measured grazing meals for Exp. I and Exp. II.

\begin{tabular}{lcccccc}
\hline \hline Variable & Exp. & Day 0 & Day 1 & Day 2 & Day 3 & Day 4 \\
\hline Dates I & I & 1 July & 2 July & 3July & 4 July & 5 July \\
& II & 9 July & 10 July & 11 July & 12 July & 13 July \\
Air temperature $\left({ }^{\circ} \mathrm{C}\right)$ & I & 26.9 & 28.0 & 25.6 & 28.6 & 25.6 \\
& II & 30.6 & 29.4 & 27.8 & 21.4 & 19.2 \\
Canopy temperature $\left({ }^{\circ} \mathrm{C}\right)$ & I & - & 21.5 & 23.4 & 27.2 & 24.4 \\
& II & - & 29.7 & 27.2 & 21.2 & 21.2 \\
Relative humidity $(\%)$ & I & 66 & 65 & 58 & 75 & 67 \\
Solar radiation $\left(\mathrm{MJ} \mathrm{m}^{-2}\right)$ & II & 66 & 72 & 70 & 81 & 93 \\
& I & 1.945 & 1.799 & 2.197 & 1.695 & 2.113 \\
& II & 2.029 & 1.966 & 1.841 & 0.16 & 0.335 \\
\hline
\end{tabular}

No significant $(\mathrm{P}>0.05)$ first residual effects of the sward compression treatments were revealed by analysis of variance and, as a consequence, only least squares means of direct effects of treatments on ingestive behavior are presented (Table 4).

The ingestive behavior of cattle during measured grazing meals was altered by sward compression. Cattle grazed compressed swards $\left(\mathrm{T}_{2}\right)$ and swards that were half-compressed $\left(\mathrm{T}_{3}\right)$ faster than they grazed normal swards $\left(\mathrm{T}_{1}\right)$ but only the contrast between normal swards and half-compressed swards $\left(\mathrm{T}_{3}\right)$ reached significance $(\mathrm{P}=0.03)$.

Herbage DM mass per bite was significantly higher for compressed $\left(\mathrm{T}_{2}\right)$ $(\mathrm{P}=0.02)$ and half-compressed swards $\left(\mathrm{T}_{3}\right)(\mathrm{P}<0.01)$ than for normal swards $\left(\mathrm{T}_{1}\right)$. The one-third greater DM mass of bites taken by cattle grazing from compressed swards was associated with an increase in sward DM mass density from 151 to $499 \mathrm{~kg} \mathrm{ha}^{-1} \mathrm{~cm}^{-1}$. It is also apparent that cattle offered compressed swards prehended and severed the herbage of about one-third of the volume of that of cattle offered normal swards. Cattle grazing compressed swards $\left(\mathrm{T}_{2}\right.$ and $\left.\mathrm{T}_{3}\right)$ prehended and severed 3 bites $\min ^{-1}$ fewer $(\mathrm{P}=0.10)$ than cattle offered normal swards.

Sward surfaces before grazing were $34 \mathrm{~cm}$ above the soil surface for normal swards and $14 \mathrm{~cm}$ above the soil surface for compressed swards. After grazing, sward surface height above the soil surface was about $16 \mathrm{~cm}$ for normal swards and nearly $14 \mathrm{~cm}$ for compressed swards.

With the design used we could not differentiate the relative amount of herbage DM intake from normal and compressed swards in the $\mathrm{T}_{3}$ treatment. Cattle offered split swards exhibited similar behavior to 
Table 4. Least squares means of selected sward variables after grazing and variables of grazing behavior of beef cattle grazing normal ( $\left.T_{1}\right)$, compressed swards $\left(\mathbf{T}_{2}\right)$, and split (normal/compressed swards) $\left(\mathbf{T}_{3}\right)($ Exp. $\mathbf{I})$.

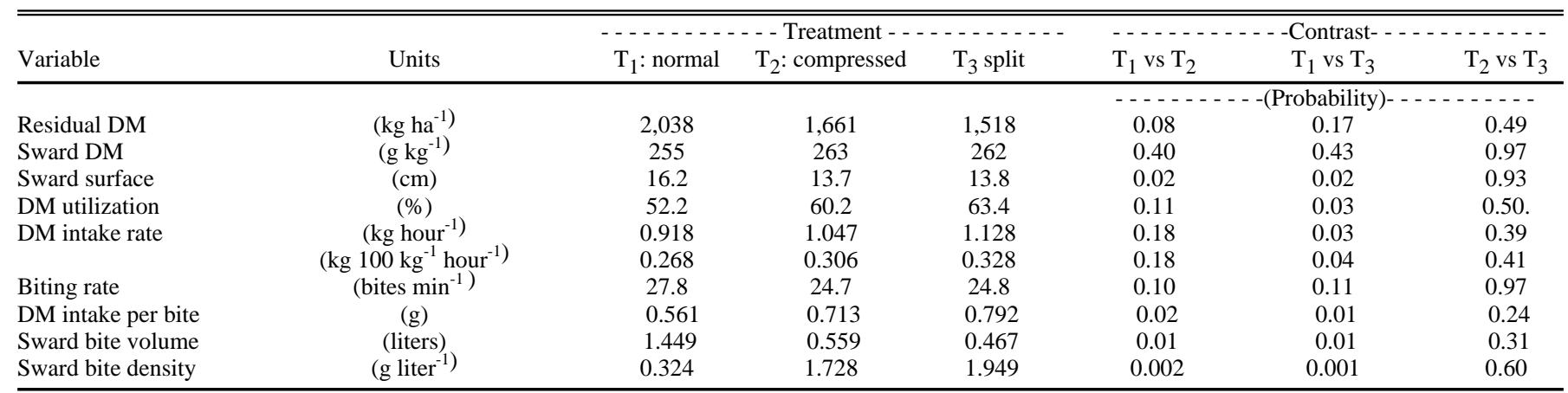

those offered compressed swards $\left(\mathrm{T}_{2}\right)$. About 54\% of bites recorded for cattle assigned to the split swards were taken from the normal segment $(\mathrm{P}>0.05)$. The higher mean bite mass of animals assigned to split swards $(\mathrm{P}<0.01)$, may indicate that more of the total ingesta came from the compressed sector.

In summary, sward compression increased sward DM density 3-fold but resulted in only small increases in rate of herbage DM intake. Herbage DM intake per bite increased less than anticipated for cattle grazing compressed swards because the increase in DM density was associated with a 3 -fold decrease in the volume of herbage prehended and severed. Slightly slower rates of biting of cattle grazing compressed swards also partially countered the effect of sward DM density on DM density per bite.

\section{Experiment II}

Herbage dry matter (DM) mass $(>5 \mathrm{~cm})$ in normal (unmodified) swards was 5,100 $\pm 745 \mathrm{~kg} \mathrm{ha}^{-1}$, sward surfaces was $27 \pm 3.4$ $\mathrm{cm}$, and herbage DM density ( $>5 \mathrm{~cm}$ ) was $246 \pm 61 \mathrm{~kg} \mathrm{ha}^{-1} \mathrm{~cm}^{-1}$ (Table 1). Compression of swards overnight lowered sward surfaces to $15.7 \pm 3.7 \mathrm{~cm}$ and raised herbage DM density $(>5 \mathrm{~cm}$ ) to $386 \pm 191$ $\mathrm{kg} \mathrm{ha}^{-1} \mathrm{~cm}^{-1}$. When normal swards were cut to $20 \mathrm{~cm}$, herbage DM mass $(>5 \mathrm{~cm})$ was depleted by $674 \mathrm{~kg} \pm 166 \mathrm{~kg} \mathrm{ha}^{-1}$ while herbage DM density $(>5 \mathrm{~cm})$ increased to $264 \pm 65 \mathrm{~kg} \mathrm{ha}^{-1} \mathrm{~cm}^{-1}$.

There were no significant residual effects $(\mathrm{P}>0.05)$ of the sward treatments in Exp. II, consequently, only least squares means of direct effects of treatments on relevant variables are presented (Table 5).

Cattle offered normal/cut swards $\left(\mathrm{T}_{2}\right)$ ingested $2.49 \mathrm{~kg}$ of herbage DM during
1 hour of grazing, while those grazing normal/compressed swards $\left(T_{1}\right)$ ingested $1.99 \mathrm{~kg}$, and those offered compressed/cut swards $\left(\mathrm{T}_{3}\right)$ ingested 2.06 $\mathrm{kg}$. Herbage DM intake by segments of normal/compressed plots $\left(\mathrm{T}_{1}\right)$ indicates that normal swards accounted for about $64 \%$ of DM intake. Intake data from normal/cut plots $\left(\mathrm{T}_{2}\right)$ shows that cattle preferred normal swards to cut swards by a ratio of 60:40. Cattle showed only slight preference for compressed swards in terms of DM intake when offered compressed/cut swards $\left(\mathrm{T}_{3}\right)$. Analysis of variance also indicated some variation in preference between animals $(\mathrm{P}=0.09)$ and between days $(\mathrm{P}=0.03)$.

One-third or less of the herbage DM allowance was consumed by grazing cattle. This indicates that intake was not limited by availability of herbage, even when cattle grazed the cut segments of $\mathrm{T}_{2}$ and $\mathrm{T}_{3}$ plots where herbage DM allowances were lowered by the removal of about $1 \mathrm{~kg}$ of herbage DM.

In terms of the proportion of bites taken from each sector, cattle took 74 and $79 \%$ of bites from normal segments when offered the choice of normal/compressed swards $\left(\mathrm{T}_{1}\right)$ or normal/cut swards $\left(\mathrm{T}_{2}\right)$, respectively. They took similar numbers of bites from each segment of compressed/cut swards $\left(\mathrm{T}_{3}\right)$.

Estimated mean herbage DM mass per bite was $1.1 \mathrm{~g}$ for cattle grazing normal sward segments $\left(T_{1}\right.$ and $\left.T_{2}\right)$ and $1.6 \mathrm{~g}$ per bite for cattle grazing compressed swards $\left(\mathrm{T}_{3}\right)(\mathrm{P}<0.05)$. We were unable to estimate bite mass of animals grazing the ' $\mathrm{B}$ ' segments (compressed, cut or cut, respectively, for $T_{1}, T_{2}$ and $T_{3}$ ) because some animals did not graze, or only took a few bites from these swards. Bite mass from the sum of 'A $+B$ ' segments indicate that bite masses during grazing of compressed segments of $T_{1}$ and $\mathrm{T}_{2}$ were higher than bite masses from the normal sward segments. The smaller bite mass of ' $A+B$ ' for $T_{3}$ reflects the smaller mass of bites taken from cut segments.

In summary, it appears that cattle preferred grazing normal swards to grazing compressed or cut swards $\left(\mathrm{T}_{1}\right.$ and $\left.\mathrm{T}_{2}\right)$.

Table 5. Least squares means of selected sward variables after grazing and variables of grazing behavior of cattle offered the choice of normal and compressed swards $\left(T_{1}\right)$, normal and cut swards $\left(T_{2}\right)$, and compressed and cut $\left(T_{3}\right)$ tall fescue swards during 1 hour grazing meals (Exp. II).

\begin{tabular}{|c|c|c|c|c|c|c|c|}
\hline \multirow[b]{2}{*}{ Variable } & \multirow[b]{2}{*}{$\begin{array}{c}\dagger \text { Code } \\
\text { A } \\
\text { B }\end{array}$} & \multicolumn{5}{|c|}{ " - - - - Treatment - - - - } & \multirow[b]{2}{*}{$\mathrm{T}_{2}$ vs $\mathrm{T}_{3}$} \\
\hline & & $\begin{array}{c}\mathrm{T}_{1} \\
\text { Normal } \\
\text { Compressed }\end{array}$ & $\begin{array}{c}\mathrm{T}_{2} \\
\text { Normal } \\
\text { Cut }\end{array}$ & $\begin{array}{c}\mathrm{T}_{3^{--}} \\
\text {Compressed }\end{array}$ & $\mathrm{T}_{1} \mathrm{vs} \mathrm{T}_{2}$ & $\begin{array}{l}\text { - Contrast } \\
\text { T1 vs T3 }\end{array}$ & \\
\hline & & & & & \multicolumn{3}{|c|}{ 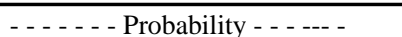 } \\
\hline \multirow[t]{3}{*}{ DM intake $(\mathrm{kg})$} & A & 1.28 & 1.49 & 1.11 & 0.29 & 0.40 & 0.06 \\
\hline & B & 0.71 & 1.00 & 0.95 & 0.14 & 0.21 & 0.81 \\
\hline & $A+B$ & 1.99 & 2.49 & 2.06 & 0.07 & 0.80 & 0.12 \\
\hline \multirow[t]{3}{*}{ DM utilization } & A & 0.33 & 0.37 & 0.29 & 0.40 & 0.41 & 0.10 \\
\hline & $\mathrm{B}$ & 0.18 & 0.33 & 0.32 & $<0.01$ & $<0.01$ & 0.98 \\
\hline & $A+B$ & 0.25 & 0.35 & 0.31 & $<0.01$ & $<0.01$ & 0.09 \\
\hline Bites $\min ^{-1}$ & $A+B$ & 28.1 & 30.6 & 28.6 & 0.15 & 0.75 & 0.26 \\
\hline Bite fraction & $\mathrm{A} /(\mathrm{A}+\mathrm{B})$ & 0.74 & 0.79 & 0.50 & 0.64 & 0.02 & $<0.01$ \\
\hline Bite DM mass (g) & $A+B$ & 1.24 & 1.36 & 1.23 & 0.36 & 0.95 & 0.33 \\
\hline
\end{tabular}


They grazed equally on compressed and cut sward segments when given the opportunity $\left(\mathrm{T}_{3}\right)$. Compressed swards supported larger bite masses than normal swards and cut swards. Cattle ingested more total herbage from normal and cut swards $\left(\mathrm{T}_{2}\right)$ than other sward treatments $\left(\mathrm{T}_{2}\right.$ and $\left.\mathrm{T}_{3}\right)$.

\section{Discussion}

\section{Herbage Intake from Normal and Compressed Swards}

Compression of vegetative grass swards by weighted plywood overnight lowered sward surfaces from 34 to 14 $\mathrm{cm}$ and resulted in a 3-fold increase in sward dry matter (DM) density. In our opinion, sward compression simulated lodging. Sward compression did not alter linear and mass dimensions of the vegetative tillers, nor did it alter the herbage DM mass of herbage DM allowance. In compressed swards, leaf blades, which reached $39 \mathrm{~cm}$ when extended, were layered in narrow horizons of about $5 \mathrm{~cm}$ depth located above the pseudostem horizon, which was about $9 \mathrm{~cm}$ above the soil surface. Arias et al. (1990) suggested that pseudostems of tall fescue swards form a mechanical barrier to prehension biting and restrict grazing to herbage above $9-11 \mathrm{~cm}$. The leaf arrangement of compressed swards was quite different from the apparently random arrangement of blades of unaltered swards where leaf angles vary widely and where fully extended blades are flagged. Thus, cattle offered compressed swards were exposed to higher sward DM densities, lower sward surface heights, and altered canopy architecture. All of these factors moderate grazing behavior (Hodgson et al. 1994).

Analysis of variance did not detect significant linear trends in herbage intake over successive days, thus we can assume that compression did not affect acceptance of normal or compressed swards and, further, that our cattle did not need to learn to graze them (Provenza and Balch 1987). It can be assumed that our cattle had been exposed to lodged swards because tall fescue pastures in Kentucky are partly or wholly lodged by the wind and the wind-driven rains that accompany thunderstorms. Each year about 50 thunderstorms are recorded at locations in the
Central Bluegrass Region of Kentucky and there are about 30 days each year with more than $25 \mathrm{~mm}$ of rain (Priddy 1993).

The dry matter (DM) intake rate was about $10 \%$ higher for cattle grazing compressed swards $\left(\mathrm{T}_{2}\right)$ than for cattle grazing normal swards $\left(\mathrm{T}_{1}\right)$. This small increase is surprising, considering that sward surfaces were lowered by more than $40 \%$ and that DM density of swards increased more than 3-fold. Higher DM intake rates of cattle grazing compressed swards were largely attributable to larger bite mass. Compressed $\left(\mathrm{T}_{2}\right)$ and split $\left(\mathrm{T}_{3}\right)$ swards resulted in mean bite DM masses that were 127 and $141 \%$ heavier, respectively, than of bites of cattle grazing normal swards $\left(\mathrm{T}_{1}\right)$.

The relatively small increase in bite mass in response to a three-fold increase in sward DM density was associated with a decline in estimated mean bite volume from 1.45 liters $\left(\mathrm{T}_{1}\right)$ to 0.56 liters $\left(\mathrm{T}_{2}\right)$ and 0.47 liters $\left(\mathrm{T}_{3}\right)$. We suggest that bite depth, an important component of bite volume (Hodgson et al. 1994), was limited to a sward horizon of about $5 \mathrm{~cm}$ in depth, delimited by a plane fixed by the top of pseudostems (Arias et al. 1990). If 0.56 liters of sward $\left(\mathrm{T}_{2}\right)$ were prehended as a $5 \mathrm{~cm}$ tall cylinder then the bite diameter would be about $19 \mathrm{~cm}$. For animals grazing the normal sward $\left(\mathrm{T}_{1}\right)$ with a bite depth of $18 \mathrm{~cm}$ and a bite volume of 1.45 liters, bite diameter would be about $10 \mathrm{~cm}$. Thus, we conclude that sward compression forced animals to take shallow bites with a wider bite area. Typically, bite depth of grazing animals is largely determined by sward properties (Laca et al. 1992), whereas bite areas are largely determined by the herbage gathering capacity of the tongue and mouth (Illius and Gordon 1987). It appears that bite mass did not fully reflect the higher DM densities of lodged swards because cattle had limited capacity to modulate bite area.

\section{Preference of Cattle for Normal or Compressed Swards}

When our grazing cattle were given a choice, over $60 \%$ of ingested herbage dry matter (DM) came from normal sward segments and the rest from compressed sward segments or cut sward segments. We concluded that this response was not related to difficulty in prehension of lodged herbage because, in Exp. I, cattle grazed compressed swards faster $\left(0.31 \mathrm{~kg}^{100 \mathrm{~kg}^{-1}}\right.$ hour $\left.^{-1}\right)$ than they grazed normal swards $(0.27 \mathrm{~kg}$ $100 \mathrm{~kg}^{-1}$ hour $\left.^{-1}\right)$. Rates of biting of 28 and 25 bites $\mathrm{min}^{-1}$ for cattle grazing normal and compressed swards, respectively, do not indicate that compressed swards were difficult to graze. This small difference in rate of biting more likely reflects its negative relationship with bite mass because animals taking larger bite masses devote more jaw movements to mastication and bolus formation (Forbes 1988).

The preference of grazing cattle for normal swards over compressed swards may be simply related to differences in sward height. When offered both, they preferred normal to compressed or cut swards. When offered compressed or cut swards, however, they expressed a slight preference for compressed swards. In Exp. II, surfaces of normal swards were $27 \mathrm{~cm}$ above the soil surface while sward surfaces of compressed and cut swards were 16 and $20 \mathrm{~cm}$, respectively. Griffiths et al. (1995) reported that their dairy cows offered the choice of 5 sward heights preferentially grazed the taller ones. They also reported that their grazing cattle did not respond to differences in bulk density of swards.

When one considers how cattle discriminated between normal and lodged swards, one concludes that the decision was probably made on the basis of vision (Illius and Gordon 1990). Field observations indicate that cattle, after entering small pastures, locate areas of taller herbage, apparently by sight, and then commence grazing. Such behavior would be prudent in the presence of predators (Newman et al. 1995). Apparently this selection process is not followed when the taller sward components are associated with dung deposits (Bao et al. 1998).

Other sensory means herbivores use in diet selection (Provenza and Balch 1987) did not appear to be involved in the decision making processes as the normal and lodged swards differed only in sward architecture. Evidently, they did not select swards because of higher energy density, as would be predicted by foraging theory (Stephens and Krebs 1986), nor did they attempt to maximize short term energy intake (Ungar et al. 1991, Distel et al. 1995). As normal and compressed swards were composed of 
similar plant material, one can assume that herbage quality characteristics were not involved in diet selection (Minson and Wilson 1994).

There was some indication that grazing was stimulated when cattle were offered normal/compressed swards and normal/cut swards. According to some reports, grazing activity may be briefly stimulated by exposure to new pastures (Dougherty et al. 1992, Forbes and Hodgson 1985), however, such aresponse is unlikely because of the briefness of grazing periods. Diet learning was probably not involved in the preference of animals for grazing normal swards over compressed swards because cattle had almost certainly been previously exposed to lodged swards in Kentucky grasslands.

Logic based on grazing down of pastures by horizon is a practical approach to modeling of grazing activity and is used in the GRAZE simulation model (Loewer 1998). Cattle graze tall grass swards down horizon by horizon until they encounter physical barriers to prehension, such as the pseudostems of tall fescue (Arias et al. 1990). Logic for advanced simulation models also requires behavior-based logic that accounts for spatial variability in herbage mass and sward surface height and patch selection (Distel et al. 1995). Our research indicates that lodging may alter patch selection in taller swards.

Knowing that grazing animals are able to maintain intake rates when grazing lodged swards may be of interest to grass breeders selecting grasses with low structural strength to facilitate intake and particle size reduction (Nguyen et al. 1982, Wright and Vincent 1996) because this trait will likely lead to increased lodging. In lodged swards, however, one can anticipate that lower crop growth rates, accelerated senescence, and declining herbage quality eventually reduce herbage intake (Minson and Wilson 1994).

\section{Conclusions}

Compression of swards is a satisfactory method of simulating short term lodging. Grazing behavior indicated that our animals were familiar with lodged swards and that they did not need to learn to graze them. Further, our cattle grazed lodged swards at slightly faster rates of intake than they grazed normal swards because they were able to compensate for lower bite depth by increasing bite area, and because the higher sward dry matter (DM) densities resulted in increased bite mass. When offered a choice, our cattle preferred grazing normal swards to lodged or defoliated swards, probably because of greater sward surface height or sward bulk. We suggest that vision was involved in the decision making process and that sight played an important role in spatial diet selection. Our data also supports simulation logic that assumes that large generalist herbivores graze pastures down, horizon by horizon.

\section{Literature Cited}

Abdel-Magid, A.H., M.J. Trlica, and R.H. Hart. 1987. Soil and vegetation responses to simulated trampling. J. Range Manage. 40:303-306.

Arias, J.E., C.T. Dougherty, N.W. Bradley, P.L. Cornelius, and L. M. Lauriault. 1990. Structure of tall fescue swards and intake of grazing cattle. Agron. J. 82:545-548.

Bailey, D.W., J.E. Gross, E.A. Laca, L.R. Rittenhouse, M.B. Coughenour, D.M. Swift, and P.L. Sims. 1996. Mechanisms that result in large herbivore grazing distribution patterns. J. Range Manage. 49:386-400.

Bao, J., P.S. Giller, and G. Stakelin. 1998. Selective grazing by dairy cows in the presence of dung and the defoliation of tall grass dung patches. Anim. Sci. 66:65-73.

Berenblut, I.I. 1964. Change-over designs with complete balance for first residual effects. Biometrics. 20:707-712.

Berenblut, I.I. 1967. The analysis of change-over designs with complete balance for first residual effects. Biometrics. 23:578-580.

Burris, W.R. and J.T. Johns. 1991. Feeding the cow herd. p. 1-14. In: The Kentucky beef book. Ky Coop. Ext. Serv. ID-108, Lexington, Ky.

Distel, R.A., E.A. Laca, T.C. Griggs, and M.W. Demment. 1995. Patch selection by cattle: maximization of intake rate in horizontally heterogeneous pastures. Appl. Anim. Behav. Sci. 45:11-21.

Dougherty, C.T., N.W. Bradley, P.L. Cornelius, and L.M. Lauriault. 1987. Herbage intake rates of beef cattle grazing alfalfa. Agron. J. 79:1003-1008.

Dougherty, C. T., L.M. Lauriault, P.L. Cornelius, and N.W. Bradley. 1989b. Herbage allowance and intake of cattle. J. Agr. Sci., Cambr. 112:395-401.
Dougherty, C.T., M. Collins, N.W. Bradley, P.L. Cornelius, and L.M. Lauriault. 1989a. Moderation of ingestive behaviour of beef cattle by grazinginduced changes of alfalfa swards. Grass Forage Sci. 45:135-142.

Dougherty, C.T., M. Collins, N.W. Bradley, L.M. Lauriault, and P.L. Cornelius. 1992. The effects of poloxalene on ingestion by cattle grazing lucerne. Grass Forage Sci. 47:180-188.

Edmonds, D.B. 1964. Some effects of sheep treading on the growth of ten pasture species. New Zeal. J. Agr. Res. 7:1-16.

Forbes, T.D.A. 1988. Researching the plantanimal interface: Investigation of ingestive behavior in grazing animals. J. Anim. Sci.. 66:2369-2379.

Forbes, T.D.A. and J. Hodgson. 1985. The reaction of grazing sheep and cattle to the presence of dung from the same or other species. Grass Forage Sci. 40:177-182.

Griffths, W. M., J. Hodgson, C. W. Holmes, and G. C. Arnold. 1995. The use of a novel approach to determine the influence of sward characteristics on the discriminatory grazing behaviour of dairy cows. Proc. New Zeal. Soc. Anim. Prod. 56:122-124.

Guthery, F.S. and R.L. Bingham. 1996. A theoretical basis for study and management of trampling by cattle. J. Range Manage. 49:264-269.

Henning, J.C. and G.D. Lacefield. 1991. Forages for beef cattle, p. 2-19. In: The Kentucky beef book. Ky. Coop. Ext. Serv. ID-108, Lexington, Ky

Herrero, M., J.B. Dent, R.H. Fawcett. 1998. The plant/animal interface in models of grazing systems, p. 495-542. In: R.M. Peart and R.B. Curry (ed.). Agricultural systems modeling and simulation. Marcel Dekker, New York.

Hodgson, J., D.A. Clark, and R.J. Mitchell. 1994. Foraging behavior in grazing animals and its impact on plant communities, p. 796-827. In: G. C. Fahey (ed.) Forage quality, evaluation, and utilization. Amer. Soc. Agron. Madison, Wis.

Illius, I.A. and I.J. Gordon. 1987. The allometry of food intake in grazing ruminants. J. Anim. Ecol. 56:989-999.

Illius, I.A. and I.J. Gordon. 1990. Constraints on diet selection and foraging behaviour in mammalian herbivores. p. 369-393. In: R.M. Hughes (ed.) Behavioural mechanisms of food selection. Springer-Verlag, Berlin.

Laca, E.A., E.D. Ungar, N.W. Seligman, and M.W. Demment. 1992. Effects of sward height and bulk density on bite dimensions of cattle grazing homogeneous swards. Grass Forage Sci. 47:91-102.

Loewer, O.J.-Jr. 1998. GRAZE: A beefforage model of selective grazing. p. 301-417. In: R.M. Peart and R.B. Curry (ed.) Agricultural systems modeling and simulation. Marcel Dekker, New York. 
Minson, D.J., and J.R. Wilson. 1994. Prediction of intake as an element of forage quality. p. 533-563. In: G. C. Fahey (ed.) Forage quality, evaluation, and utilization. Amer. Soc. Agron. Madison, Wis.

Newman, J.A., A.J. Parsons, J.H.M Thornley, P.D. Penning, and J.R. Krebs. 1995. Optimal diet selection by a generalist grazing herbivore. Functional Ecol. 9:255-268.

Nguyen, H.T., D.A. Sleper, and A.G. Matches. 1982. Inheritance of forage quality and its relationship to leaf tensile strength in tall fescue. Crop Sci. 22:67-72.

Priddy, K. T. 1993. Kentucky climate: 19611990. Monthly normals of temperature, precipitation and frost dates. Univ. Ky. Agr. Exp. Sta. PR-352, Lexington, Ky.
Provenza, F.D. and D.F. Balch. 1987. Diet learning by domestic ruminants: Theory, evidence and practical applications. Appl. Anim. Behav. Sci. 18:211-232.

Quenouille, M.H. 1953. The design and analysis of experiments. Charles Griffin and Co., London, U.K.

SAS Institute Inc. 1997. SAS/STAT ${ }^{\circledR}$ Software: Changes and Enhancements through release 6.12. SAS Inst. Inc. Cary, N.C.

Sheath, G.W. and W.T. Carlson. 1998. Impact of cattle treading on hill land. 1. Soil damage patterns and pasture status. New Zeal. J. Agr. Res. 41:271-278.

Stephens, D. W., and J. R. Krebs. 1986. Foraging theory. Princeton University Press, New Jersey.
Taylor, T.H., and W.C. Templeton Jr. 1976. Stockpiling Kentucky bluegrass and tall fescue forage for winter pasturage. Agron. J. 68:235-239.

Ungar, E.D., A. Genizi, and M.W. Demment. 1991. Bite dimensions and herbage intake by cattle grazing short hand-constructed swards. Agron. J. 83:973-978.

Wright, W. and J.F.V. Vincent. 1996. Herbivory and the mechanics of fracture in plants. Biol. Reviews Cambridge Philosophical. Soc. 71:401-413. 